\title{
Pengasuhan Demokratis dalam Pengembangan Sosial Emosional Anak Usia Dini di Tempat Penitipan Anak Ibunda Ponorogo
}

\author{
Suci Midsyahri Azizah \\ Institut Agama Islam Sunan Giri Ponorogo \\ Email: sucimidsyahri88@gmail.com
}

\begin{abstract}
Early childhood grows and develops so fast one of which is social development. Child Care Center (TPA) is one way for children to continue to get good education and care as long as parents are busy working. This study uses a research approach that is qualitative with the type of research that is a case study. This research was conducted in Ibunda Child Care Center Jln. Sumatra Banyudono Ponorogo, using data collection techniques namely by observation, interview, documentation and triangulation techniques. Based on the analysis of the data it can be concluded that, firstly, the parenting strategies carried out in the Ibunda's Day Care Center use democratic parenting by promoting children's social emotion based on children's enthusiasm, feeling happy and happy and not giving rules that curb children's expression. The rules that are made in TPA are to control the attitudes and traits for the purpose of forming a better character. Secondly, the implications of the pattern of democratic care in the Ibunda's Child Care Center have a significant positive effect. The children who are entrusted to the TPA, become more confident, independent, and can be more friendly and have good self-control.
\end{abstract}

Keywords: Child Care Center, Democratic Care, Emotional Social And Early Childhood

\section{Pendahuluan}

Anak usia dini tumbuh dan berkembang begitu cepat salah satunya adalah perkembangan sosial. Perkembangan sosial ini nantinya bisa membentuk perilaku anakanak menjadi manusia dewasa yang baik. Perilaku anak-anak bisa dipengaruhi dari dan dimana anak tersebut tumbuh dan berkembang, ini disebabkan karena anak-anak cepat menirukan apa yang lingkungan atau orang lain lakukan.

Anak adalah makhluk sosial. Anak selalu tertarik pada apa yang dilakukan oleh orang lain dan ia memiliki kecenderungan untuk menirukan apapun yang dilihat dan yang di dengar. Maka dari itu anak harus di asuh pada pengasuh yang baik dan tepat.

Perkembangan sosial emosional adalah suatu perkembangan yang sulit dipisahkan secara tegas satu sama lainnya. ${ }^{1}$ Kelekatannya semakin kuat apabila ekspresi dari perpaduan keduanya dimunculkan oleh anak-anak yang berada pada kelompok umur pra sekolah. Sulit ditentukan faktor yang berpengaruh pada ekspresi seorang anak apakah akibat ketidakmampuan bersosialisasi ataukah karena belum bisa mengendalikan emosinya. Misalnya, seorang anak bermain bersama-sama dengan teman-temannya, tibatiba anak tersebut keluar dari kelompok bermainnya dan mengadukan kepada pengasuhnya. Hal ini disebabkan karena anak tersebut tidak mampu bersosialilasi ataukah anak tersebut tidak mampu mengendalikan emosinya.

\footnotetext{
1 Ali Nugraha, Metode Pengembangan Sosial Emosional (Tangerang: Universitas Terbuka, 2012), 3.2.
} 
Pengasuhan yang dilakukan orang tua sangat berperan penting bagi tumbuh kembang anak. Pengasuhan merupakan suatu cara terbaik yang dapat ditempuh orang tua dalam mendidik anak-anaknya sebagai perwujudan dari rasa tanggung jawab kepada anak-anaknya sehingga perlakuan orang tua terhadap anaknya memberikan andil sangat baik dalam proses pembentukan karakter anak. Keluarga yang utamanya merupakan pendidikan pertama kali bagi anak. Setiap orang tua mengharapkan anak-anaknya menjadi anak yang berperilaku baik, oleh karena itu dalam membentuk karakter anak harus diberikan pengasuhan yang baik sejak dini. Hal ini disebabkan karena pendidikan pertama yang diterima oleh anak adalah pendidikan dari orang tua.

Keadaan orang tua khususnya ibu yang sibuk bekerja akan mengurangi waktu kebersamaan bersama anak. Dengan demikian kedekatan ibu dengan anak pun menjadi berkurang. Suatu konsekuensi logis dari ibu rumah tangga yang biasanya mendidik anak mulai digantikan peranannya oleh pembantu rumah tangga yang terkadang mempunyai banyak permasalahan baik dari segi biaya maupun pengetahuan yang masih sangat rendah dalam mengasuh dan mendidik anak.

Taman Penitipan Anak (TPA) merupakan salah satu bentuk satuan PAUD jalur pendidikan nonformal yang menyelenggarakan program pendidikan bagi anak sejak lahir sampai dengan usia 6 (enam) tahun dengan prioritas sejak lahir sampai usia 4 tahun. $^{2}$

TPA adalah salah satu cara agar anak tetap mendapatkan pendidikan serta pengasuhan yang baik selama orang tua sibuk bekerja. TPA bukanlah sekedar gedung tempat menitipkan anak dimana kebutuhan makan dan mandi adalah prioritas utama mereka tetapi fungsi TPA juga diperluas yaitu dengan memberikan nilai-nilai edukatif bagi anak sebagai bekal pengetahuan dan pengembangan maupun pembentukan perilaku. TPA diharapkan menjadi lembaga yang dapat membantu mendidik anak dengan baik, yang dapat menghindarkan kemungkinan anak terlantar dan ibu dapat bekerja dengan tenang.

\section{Kajian Teoritik}

Anak usia dini adalah sosok individu yang sedang menjalani suatu proses perkembangan dengan pesat dan fundamental bagi kehidupan selanjutnya. ${ }^{3}$ Disampaikan oleh NAEYC (National Association for The Education of Young Children), yang mengatakan bahwa anak usia dini adalah anak yang berada pada rentang usia 0-8 tahun, yang tercakup dalam program pendidikan di taman penitipan anak, penitipan anak pada keluarga (family child care home), pendidikan pra sekolah baik swasta maupun negeri, TK, dan SD. Sedangkan Undang-Undang Republik Indonesia Nomor 20 Tahun 2003 tentang Sistem Pendidikan Nasional pada Pasal 1 ayat 14 menyatakan bahwa pendidikan anak usia dini adalah suatu upaya pembinaan yang ditujukan kepada anak sejak lahir sampai dengan usia enam tahun yang dilakukan melalui pemberian rangsangan

${ }^{2}$ Direktorat Pembinaan Pendidikan Anak Usia Dini Direktorat Jenderal Pendidikan Anak Usia Dini Dan Pendidikan Masyarakat Kementerian Pendidikan Dan Kebudayaan, Petunjuk Teknis Penyelenggaraan Taman Penitipan Anak (TT: TP. 2015), 5.

${ }^{3}$ Yuliani Nurani Sujiono, Konsep Dasar Pendidikan Anak Usia Dini (Jakarta: Indeks. 2011), 6. 
pendidikan untuk membantu pertumbuhan dan perkembangan jasmani dan rohani agar anak memiliki kesiapan dalam memasuki pendidikan lebih lanjut. Sementara itu, UNESCO dengan persetujuan Negara-negara anggotanya membagi jenjang pendidikan menjadi 7 jenjang yang disebut International Standard Classification of Education (ISDEC). Pada jenjang yang ditetapkan UNESCO tersebut, pendidikan anak usia dini termasuk pada level 0 atau jenjang pra sekolah, yaitu untuk anak usia 3-5 tahun. Dalam implementasinya di beberapa Negara, pendidikan usia dini menurut UNESCO ini tidak selalu dilaksanakan sama, seperti jenjang usianya. ${ }^{4}$

Perkembangan awal (0-5) tahun adalah masa-masa kritis yang akan menentukan perkembangan adanya perbedaan tumbuh kembang anak satu dengan lainnya, yang dipengaruhi oleh, 1) faktor lingkungan sosial yang menyenangkan anak, 2) Faktor emosi, 3) metode emndidik anak, 4) beban tanggung jawab yang berlebihan, 5) faktor keluarga dimasa kanak-kanak, dan 6) faktor rangsangan lingkungan. ${ }^{5}$

Perkembangan sosial adalah proses kemampuan belajar dan tingkah laku yang berhubungan dengan individu untuk hidup sebagai bagian dari kelompoknya. Perkembangan sosial anak dibentuk dari lingkungan sekitar, anak-anak diharapkan bisa bersosialisasi dengan baik sesuai dengan tahap perkembangan di usianya, dan cenderung menjadi anak yang mudah bergaul. ${ }^{6}$

Otak emosional berpusat di dalam sistem limbic. Sistem ini secara evolutif jauh lebih tua daripada bagian cortex celebri karena sistem limbic tumbuh dan berkembang lebih awal dari cortex celebri. Artinya, pada awalnya bagian otak yang pertama muncul adalah sistem libik. Fungsi sistem limbic adalah pengaturan emosi. Hal ini menunjukkan bahwa perkembangan otak manusia dimulai dengan pikiran emosional sebelum pikiran rasional berfungsi. Oleh karena itu, otak anak-anak pada dasarnya adalah otak emosional, bukan otak rasional. Atas dasar ini, pembelajaran yang efektif pada anak-anak adalah stimulasi emosionalitas, seperti memberikan rasa gembira, semangat, antusias, dan lain-lain. ${ }^{7}$

Ada beberapa keadaan emosi berikut ini yang mempengaruhi penyesuaian pribadi dan sosial anak. ${ }^{8}$

a. Emosi menambahkan rasa nikmat bagi pengalaman sehari-hari.

b. Emosi menyiapkan tubuh untuk melakukan tindakan.

c. Ketegangan emosi mengganggu keterampilan motoric.

d. Emosi merupakan suatu bentuk komunikasi.

${ }^{4}$ Siti Aisyah, dkk, Perkembangan dan Konsep Dasar Pengembangan Anak Usia Dini (Tangerang Selatan: Universitas Terbuka, 2015), 1.3.

5 Suyadi, Teori Pembelajaran Anak Usia Dinidalam Kajian Neurosains (Bandung: Remaja Rosdakarya, 2015), 22.

${ }^{6}$ Ayuda Jati Putri Hermien Laksmiwati, "Perkembangan Sosial Anak Usia Dini Di Taman Penitipan Anak (TPA) Melati School Ketintang Tengah - Surabaya", jurnal Character, Volume 02 Nomor 02 (Tahun 2013), 5.

${ }^{7}$ Suyadi, Teori Pembelajaran Anak Usia Dinidalam Kajian Neurosains (Bandung: Remaja Rosdakarya, 2015), 119.

8 Siti Aisyah, dkk, Perkembangan dan Konsep Dasar Pengembangan Anak Usia Dini (Tangerang Selatan: Universitas Terbuka, 2015), 9.7. 
e. Emosi mengganggu aktivitas mental.

f. Emosi merupakan sumber penilaian diri dan sosial.

g. Emosi mewarnai pandangan anak terhadap kehidupan.

h. Emosi mempengaruhi interaksi sosial.

i. Emosi memperlihatkan kesannya pada ekspresi wajah.

j. Emosi mempengaruhi susasan psikologis.

k. Reaksi emosional apabila diulang-ulang akan berkembang menjadi kebiasaan.

Faktor yang mempengaruhi perkembangan sosial dan emosi anak usia dini adalah sebagai berikut:?

a. Faktor hereditas

Faktor hereditas merupakan karakteristik bawaan yang diturunkan daro orang tua biologis atau orang tua kandung kepada anaknya. Faktor hereditas tersebut mempengaruhi kemampuan intelektual yang salah satunya dapat menentukan perkembangan sosial dan emosi seorang anak.

Pembawaan yang telah ada pada anak sejak dilahirkan itulah yang menentukan perkembangannya dikemudian hari. Menurut aliran ini, pendidikan dan lingkungan sama sekali tidak berpengaruh terhadap perkembangan seorang anak, termasuk perkembangan sosial dan emosinya. Dalam perspektif hereditas, perkembangan seoranga anak dipengaruhi oleh hal-hal berikut:

1) Bakat. Setiap anak memiliki bakat tertentu. Yang mana bakat tersebut diwariskan oleh orang tuanya. Bakat juga sangat berpengaruh terhadap perkembangan sosial dan emosi seorang anak.

2) Sifat-sifat keturunan. Sifat-sifat keturunan yang diwariskan oleh orang tuanya bisa berupa fisik dan psikisnya. Fisik yang beupa bentuk badan, penyakit, dan lain-lain. Adapun bentuk psikis yang berupa sifat pemalas, sifat pemarah, pandai dan lain-lain.

b. Faktor lingkungan

Faktor lingkungan diartikan sebagai kekuatan yang kompleks dari dunia fisik dan sosial yang memiliki pengaruh terhadap susunan biologis serta pengalaman psikologis, termasuk pengalaman sosial dan emosi anak sejak sebelum ada dan sesudah ia lahir. Faktor lingkungan ini meliputi semua pengaruh lingkungan, termasuk didalamnya pengaruh-pengaruh berikut ini:

1) Keluarga

Pola asuh ornag tua, sikap, serta situasi dan kondisi yang sedang melingkupi orang tua dapat memberikan pengaruh terhadap perkembangan sosial dan emosi anak. Misalnya saja saat orangtua menerapkan pola asuh otoriter terhadap anak. Pola asuh otoriter tersebut cenderung memaksakan kepada anak untuk selalu menuruti perintah orang tuanya. Kecenderunga tersebut menjadikan anak merasa tertekan yang pada akhirnya ia akan menjadi

${ }_{9}^{9}$ Novan Ardi Wiyani, Mengelola dan Mengembangkan Kecerdasan Sosial dan Emosi Anak Usia Dini (Yogyakarta: Ar-Ruz Media, 2014), 43. 
sosok anak yang menutup diri da pergaulan orang lain. Sebaliknya, jika orang tua menerpakan pola asuh demokratis, anak akan menjadi sosok yang berpikiran terbuka (fairness) yang menjadikan ia mampu bergaul dan memiliki jiwa sosial yang tinggi. Keadaan ekonomi dan status sosial orang tua juga ikut memengaruhi perkembangan sosial dan emosi anak.

2) Sekolah

Sekolah merupakan lingkungan kedua bagi anak, disekolah anak berhubungan dengan pendidik PAUD dan teman sebayanya. Pola asuh dan perilaku yang ditampilkan oleh pendidik PAUD dihadapan anak dan juga perilaku teman sebayanya juga dapat memengaruhi perkembangan sosial emosional seorang anak.

3) Masyarakat

Budaya, kebiasaan, agama, dan keadaan demografi pada suatu masyarakat diakui ataupun tidak memiliki pengaruh dalam perkembangan sosial dan emosi anak usia dini. Misalnya, seorang yang dibesarkan di perkotaan perkembangannya akan berbeda dengan anak yang dibesarkan di pedesaan. Kebiasaan pada suatu masyarakat dapat memengaruhi cara belajar dan hasil belajar anak, religiusitas suatu masyarakat juga akan sangat menentukan dalam perkembangan sosial dan emosi anak usia dini.

c. Faktor umum

Faktor umum yang dapat memengaruhi perkembangan anak usia dini antara lain:

1) Jenis kelamin

Biasanya anak laki-laki cenderung akan mengatasi masalahnya dengan logika, sedangkan anak perempuan cenderung mengatasi masalahnya dengan perasaan atau emosinya. Dalam konteks pergaulan sosial, hal itu menjadikan nak perempuan lebih mudah berempati daripada anak laki-laki.

2) Kelenjar gondok

Hasil riset dalam bidang endocrinology menunjukkan betapa vitalnya peranan yang dimainkan kelenjar gondok terhadap perkembangan fisik motoric dan psikis, termasuk perkembangan sosial dan emosi anak usia dini. Kelenjar gondok tersebut memengaruhi perkembangannya, baik pada waktu sebelum lahirmaupun pada pertumbuhan dan perkembangan sesudahnya.

3) Kesehatan

Anak yang kesehatan fisik dan psikisnya baik dan sempurna akan mengalami pertumbuhan dan perkembangan yang memadai, termasuk perkembangan sosial dan emosinya. Keadaan fisik dan psikis yang sempurna akan memudahkan seorang anak dalam bergaul dengan orang lain.

Perkembangan sosial emosional yang sehat pada anak hanya dapat terjadi jika anak dekat dengan orang tua atau pengasuhnya. Seperti hubungan pendukung untuk mengembangkan kepercayaan dan rasa percaya diri, 
kemampuan menjalin hubungan dengan orang lain, dan menyelesaikan masalah serta kebutuhan untuk berhasil dalam pelajaran di sekolah dan kehidupan.

Taman Penitipan Anak (TPA) merupakan bentuk layanan Pendidikan Anak Usia Dini (PAUD) Non-Formal yang terus berkembang jumlahnya. Taman Penitipan Anak telah dikembangkan oleh Departemen Sosial sejak tahun 1963 sebagai upaya untuk memenuhi kebutuhan pengasuhan, pembinaan, bimbingan, sosial anak balita selama anak tidak bersama orangtua. ${ }^{10}$

Pengalaman peserta didik di dalam keluarga dan di lembaga PAUD berpengaruh besar terhadap positif atau tidaknya peserta didik ketika belajar. Layanan TPA yang berkualitas memiliki prinsip yang khas, meliputi: Tempa, Asah, Asih, Asuh. ${ }^{11}$

a. Tempa. Yang dimaksud dengan tempa adalah untuk mewujudkan kualitas fisik anak usia dini melalui upaya pemeliharaan kesehatan, peningkatan mutu gizi, olahraga yang teratur dan terukur, serta aktivitas jasmani sehingga peserta didik memiliki fisik kuat, lincah, daya tahan dan disiplin tinggi.

b. Asah. Asah berarti memberi dukungan kepada peserta didik untuk dapat belajar melalui bermain agar memiliki pengalaman yang berguna dalam mengembangkan seluruh potensinya. Kegiatan bermain yang bermakna, menarik, dan merangsang imajinasi, kreativitas peserta didik untuk melakukan, mengekplorasi, memanipulasi, dan menemukan inovasi sesuai dengan minat dan gaya belajar peserta didik

c. Asih. Asih pada dasarnya merupakan penjaminan pemenuhan kebutuhan peserta didik untuk mendapatkan perlindungan dari pengaruh yang dapat merugikan pertumbuhan dan perkembangan, misalnya perlakuan kasar, penganiayaan fisik dan mental dan ekploitasi.

d. Asuh. Melalui pembiasaan yang dilakukan secara konsisten untuk membentuk perilaku dan kualitas kepribadian dan jati diri peserta didik dalam hal, yaitu:

1) integritas, iman, dan taqwa;

2) Patriotisme, nasionalisme dan kepeloporan;

3) Rasa tanggung jawab, jiwa kesatria, dan sportivitas;

4) Jiwa kebersamaan, demokratis, dan tahan uji;

5) Jiwa tanggap (penguasaan ilmu pengetahuan, dan teknologi), daya kritis dan idealisme;

6) Optimis dan keberanian mengambil resiko;

7) Jiwa kewirausahaan, kreatif dan profesional.

${ }^{10}$ Direktorat Pembinaan Pendidikan Anak Usia Dini Direktorat Jenderal Pendidikan Anak Usia Dini Dan Pendidikan Masyarakat Kementerian Pendidikan Dan Kebudayaan, Petunjuk Teknis Penyelenggaraan Taman Penitipan Anak (TT: TP. 2015), 11-12

${ }_{11}$ Direktorat Pembinaan Pendidikan Anak Usia Dini Direktorat Jenderal Pendidikan Anak Usia Dini Dan Pendidikan Masyarakat Kementerian Pendidikan Dan Kebudayaan, Petunjuk Teknis Penyelenggaraan Taman Penitipan Anak (TT: TP. 2015), 11-12 
Pengasuhan demokratis adalah pengasuhan yang ditandai dengan pengakuan orang tua terhadap kemampuan anak-anaknya dan kemudian anak diberi kesempatan untuk tidak selalu tergantung kepada orang tua. Pengasuhan seperti ini orang tua memberi sedikit kebebasan kepada anak untuk memilih apa yang dikehendaki dan apa yang diinginkan yang terbaik bagi dirinya. ${ }^{12}$

Dalam bukunya Tridonanto menjelaskan bahwa pola asuh demokrasi adalah pola asuh orang tua yang menerapkan perlakuan kepada anak dalam rangka membentuk kepribadian anak dengan cara memprioritaskan kepentingan anak yang bersikap rasional atau pemikiran-pemikiran. Pola asuh demokrasi mempunyai ciri-ciri, yaitu: ${ }^{13}$

a. Anak diberi kesempatan untuk mandiri dan mengembangkan control internal.

b. Anak diakui sebagai pribadi oleh orang tua dan turut dilibatkan dalm pengambilan keputusan.

c. Menetapkan peraturan serta mengatur kehidupan anak.

d. Memprioritaskan kepentingan anak, akan tetapi tidak ragu-ragu mengendalikan mereka.

e. Bersikap realistis terhadap kemampuan anak, tidak berharap yang berlebihan yang melampaui kemampuan anak.

f. Memberikan kebebasan kepada anak untuk memilih dan melakukan suatu tindakan.

g. Pendekatannya terhdap anak bersifat hangat.

Adapun dampak dari pola asuh demokratis ini, bisa membentuk perilaku anak seperti:

a. Memiliki rasa percaya diri.

b. Bersikap bersahabat.

c. Mampu mengendalikan diri (self control)

d. Bersikap sopan.

e. Mau bekerja sama.

f. Memiliki ras ingin tahunya yang tinggi

g. Mempunyai tujuan atau arah hidup yang jelas.

h. Berorientasi terhadap prestasi.

Berikut ini adalah beberapa indicator-indikator pendukung dari pola asuh demokratis,

a. Kedisiplinan

Disiplin adalah suatu sikap menghormati, menghargai, dan mentaati segala peraturan dan ketentuan yang berlaku. Sedangkan dalam kamus besar bahasa Indonesia mengandung makna sebagi latihan batin dan watak dengan maksud supaya segala perbuatannya selalu mentaati tata tertib.

12 Mansur, Pendidikan Anak Usia Dini Dalam Islam (Yogyakarta: Pustaka Pelajar, 2005), 353. 2014), 16 .

13 Al. Tridhonanto, Mengembangkan Pola Asub Demokratis (Jakarta: PT Alex Media Komputindo, 
Cara terbaik untuk membantu anak belajar disiplin diri, dengan membiarkan anak bertanggung jawab di setiap bidang dalam hidupnya, bahkan saat anak memilih untuk tidak melakukannya. Adapun peran kedisiplinan sedini mungkin penting, mengingat tanpa kedisiplinan tujuan pendidikan atau tujuan dari segala aktivitas yang dilakukan seseorang sulit terwujud, dalam hal inilah peran orang atau guru adalah menanamkan sikap disiplin terhadap anak.

b. Kebersamaan

Kebersamaan dalam arti kerjasama. Kerjasama merupakan kebutuhan yang sangat penting bagi kelangsungan hidup. Tanpa kerjasama tidak aka ada individu, keluarga, oraganisasi masyarakat.

c. Kegotong Royongan

Setiap agama tidak ada terkecuali selalu mengajarkan seseorang untuk hidup dalam kegotongroyongan. Bila sejak usia dini sudah ditanamkan sikap yang demikian, kelak akan terlatih dan bersikap hidup dalam penuh kegorong royongan.

Pola asuh demokratis sangat erat kaitannya dengan membangun komunikasi yang menyenangkan. Ciri-ciri komunikasi yang baik adalah sebagai brikut,

a. Keterbukaan

Keterbukaan adalah sejauh mana individu memiliki keinginan untuk terbuka dengan orang lain dalam berinteraksi. Keterbukaan yang terjadi dalam komunikasi memungkinkan perilaku agar dapat memberikan tanggapan secara jelas terhadap segala pikiran dan perasaan yang diungkapkannya.

b. Empati

Empati adalah suatu perasaan individu yang merasakan sama seperti yang dirasakan orang lain, tanpa harus secara nyata terlibat dalam perasaan ataupun tanggapan orang tersebut.

c. Dukungan

Adanya dukungan dapat membantu seseorang lebih bersemangat dalam melakukan aktivitas serta meraih tujuan yang diinginkan. Dukungan ini lebih diharapkan dari terdekat yaitu keluarga

d. Perasaan positif

Perasaan yaitu dimana individu mempunyai perasaan positif terhadap apa yang sudah dikatakan orang lain terhadap dirinya.

e. Kesamaan

Kesamaan adalah sejauh mana antara pembicara sebagai pengirim pesan dengan pendengar sebagai penerima pesan mencapai kesamaan dalam arti dan pesan komunikasi. 


\section{Metode Penelitian}

Jenis penelitian ini ialah penelitian studi kasus. Jenis penelitian studi kasus merupakan penelitian yang memfokuskan pada satu fenomena saja yang dipilih untuk dipahami secara mendalam. Penelitian ini bertujuan untuk menggambarkan realitas yang kompleks tentang gejala atau keadaan. ${ }^{14}$ Peneliti bermaksud untuk melakukan pengamatan secara mendalam mengenai pengasuhan demokratis dalam pengembangan sosial emosional anak usia dini di Taman Penitipan Anak (TPA) Ibunda Ponorog.

Teknik pengumpulan data yang digunakan dalam penelitian ini adalah observasi, wawancara dan dokumentasi. Observasi peneliti ini terfokus pada proses pengasuhan demokratis yang ada di TPA Ibunda. Wawancara pada penelitian ini menggunakan teknik purposive sampling, yaitu peneliti memilih sampel atau responden dengan cara memilih orang tua yang telah lama menitipkan anaknya di TPA Ibunda. Minimal telah menitipkan anaknya selama satu tahun. Dan juga menggunakan teknik snowball sampling yaitu pada awalnya peneliti memilih responden dari orang tua siswa sebanyak 3 orang. Disitu peneliti merasa kurang dalam penggalian data. Maka peneliti menambah jumlah responden yang berasal dari orang tua siswa TPA Ibunda. Selain itu peneliti juga mengambil responden dari sebagian pengasuhnya. Dokumentasi yang diambil dari penelitian ini adalah catatan-catatan kegiatan pengasuh, serta foto-foto kegiatan yang diikuti siswa TPA Ibunda ketika di TPA.

Analisis data dalam penelelitian kualitatif, dilakukan pada saat pengumpulan data berlangsung, dan setelah selesai pengumpulan data dalam periode tertentu. Teknik analisis data pada penelitian ini meliputi: reduksi data, penyajian data dan penarikan kesimpulan. Kemudian, data tersebut di uji kebenarannya melalui triangulasi data. Triangulasi data diartikan sebagai teknik pengumpulan data yang bersifat menggabungkan dari berbagai teknik pengumpulan data dan sumber data yang telah ada. $^{15}$

\section{Hasil dan Pembahasan}

Taman Penitipan Anak (TPA) Ibunda merupakan salah satu bentuk layanan jalur pendidikan nonformal yang menyelenggarakan program pendidikan dan pengasuhan bagi anak sejak lahir sampai dengan usia 5 (enam) tahun. Dr hasil observasi yang peniliti lakukan, di TPA Ibunda terdapat anak-anak yang dititipkan mulai usia 1 bulan samapai dengan 5 tahun. Anak-anak yang masih sangat muda atau bayi, maka dipegang oleh satu orang pengasuh. Anak yang usianya sudah 7 bulan keatas maka satu pengasuh memegang lebih dari 3 anak, yaitu dengan cara anak di letakkan di babywalker, sedangkan pengasuhnya mengawasi dan mengajaknya bermain. Sedangkan anak yang usianya 1 sampai dengan 24 bulan anak-anak bisa bermain bebas dengan pengawasan pengasuh yang penuh. Pada kelompok anak yang usianya diatas 25 bulan sampai dengan 5 tahun anak di beri kelas layaknya anak yang sekolah di playgroup. Pada kelompok ini pengasuh

${ }^{14}$ Nana Syaodih Sukmadinata, Metode Penelitian Pendidikan (Bandung: Remaja Rosdakarya, 2005),

15 Sugiyono, Metode Penelitian Kuantitatif, Kualitatif, dan R\&D (Bandung: Alfabeta, 2018), 224 
yang memegang adalah pengasuh khusus yaitu ada dua orang pengasuh, ibu Dwi dan Ibu Luki. Dalam pengasuhan di TPA Ibunda menerapkan konsep membangun ketertarikan/antusias anak, senang dan gembira. Contohnya: nyanyi, menggambar sesuai ekspresi mereka, dan masih banyak lagi.

Selain itu, di TPA Ibunda sudah ada jadwal kegiatan terstruktur. Untuk kelompok usia anak 2 tahun sampai 5 tahun, mulai jam 8 sampai jam 10 dibuat buat kelas seperti layaknya kelas playgrup. Pada kelompok ini para pengasuh menperhatikan emosional anak yang berbasis pada antusiasme, rasa senang, gembira serta keingintahuan, konsep ini sesuai dengan teori yang dikemukakan oleh Suyadi, dalam bukunya Teori Pembelajaran Anak Usia Dini dalam Kajian Neurosains. Contohnya, anak-anak diajak bernyanyi, bermain peran, mewarnai, dan masih banyak lagi.

Pembelajaran yang demokratis terlihat Nampak jelas di Taman Penitipan Anak Ibunda, disana tidak pernah mengekang murid/anak dengan larangan-larangan yang mengikat kuat salah satu contoh anak boleh membawa mainan. Menurut peneliti cara ini adalah salah satu bentuk konkrit sebuah lembaga dalam mengawal serta mengarahkan ekspresi anak untuk lebih terarah, dan terkontrol.

Dari hasil wawancara dengan salah satu pengasuh, di TPA ibunda sudah disediakan beberapa mainan untuk media bermain anak-anak. Seperti puzzle, lego, kudakuda an, bola, peralatan masak-masakan dan lain-lain. Akan tetapi disini kami membebaskan bagi anak-anak yang pengin bawa mainan sendiri, tapi dengan syarat yaitu boleh dipinjam temannya apabila temannya pengin pinjam.

Selain itu, di TPA Ibunda selain ada peraturan yang sudah dibuat dari pihak pengurus TPA. Misalnya anak selalu kita ajarkan untuk membiasakan bilang minta tolong, terima kasih, minta maaf, datang maupun pulang mengucapkan salam dan berjabat tangan. Dan juga ada peraturan-peraturan yang dibuat bersama-sama dengan anak-anak didik. Peraturan yang dibuat bersama anak-anak contohnya, ketika anak-anak bawa jajan dari rumah, maka aturannya adalah mau berbagi jajan apabila ada temannya yang memintanya. Begitu juga, apabila anak-anak membawa mainan sendiri dari rumah, maka aturannya adalah boleh dipinjam temannya apabila ada temannya yang pengin pinjam mainan.

Selanjutnya, pemberian rasa nyaman kepada anak selalu diberikan oleh setiap pengasuh yang berada pada Tempat Penitipan Ibunda, TPA ini dimodel dan disetting serta dibuat senyaman mungkin layaknya rumah kedua dan orang tua kedua. Dari hasil wawancara bersama Ibu Nana yaitu, ketika ada anak yang menangis, usia 1 tahun kebawah, maka pengasuh segera menggendongnya dan mencari tau penyebab anak menangis. Dan begitu juga ketika anak yang menangis itu anak yang agak besar maka pengasuh segera mencari tau penyebabnya. Dan segera membujuknya agar diam. Semua pengasuh berusaha menganggap anak-anak itu seperti anaknya sendiri. Dengan penuh kasih sayang mereka mengasuh anak-anak di TPA. Para pengasuh berusaha agar anakanak nyaman dengan mereka. Selain itu anak-anak juga merasa disayangi, dikasihi dengan penuh oleh para pengasuhnya. Sehingga anak-anak krasan dan tidak rewel ketika berada di TPA. Dan dengan begitu para orang tua percaya pada TPA Ibunda walau TPA 
Ibunda yang sederhana. Cara para pengasuh untuk mendekatkan diri dengan anak-anak, yaitu dengan cara membangun komunikasi yang baik dengan anak-anak. Pengasuh selalu senyum ketika menyambut anak-anak, berbicara dengan anak-anak dengan cara yang baik, dan selalu memberikan perhatian penuh kepada anak-anak. Ini dilakukan dalam kondisi dan situasi apapun. Mereka selalu menghargai apa yang dikatakan anak-anak. Mereka juga selalu mendukung apapun yang dilakukan anak-anak selagi itu positif dan tidak membahayakan anak-anak.

Dari paparan-paparan diatas jelas bahwasannya, pengasuhan yang ada di Taman Penitipan Ibunda itu cenderung menggunakan pola pengasuhan demokratis. Yang mana pola pengasuhan ini salah satunya bertujuan untuk mengoptimalkan perkembangan anak yang khususnya perkembangan sosial emosional anak usia dini.

Pernyataan di atas dapat diambil kesimpulan bahwa, segala bentuk dalam pengasuhan menggunakan gaya pengasuhan demokratis dengan mengedepankan sosial emosional anak yang berlandaskan pada antusiasme anak, rasa senang dan gembira serta tidak memberikan aturan yang mengekang ekspresi anak. Aturan-aturan yang dibuat di TPA adalah untuk mengontrol sikap dan sifat demi terarahnya kepada pembentukan karakter yang lebih baik.

Adapun hasil dari pengasuhan yang dilakukan pada Tempat Penitipan Anak Ibunda bisa langsung dirasakan oleh para wali murid. Mereka mengungkapkan anaknya menjadi semakin pintar, walaupun anaknya masih berusia dibawah 3 tahun sudah banyak hal yang bisa dilakukan, misalnya; mengucapkan niat wudlu, hafal gerakan shalat, mandiri, dan masih banyak hal lagi.

Perubahan lain yang dirasakan oleh para wali murid, anak mereka yang awalnya adalah anak yang tidak punya rasa kepercayaan diri menjadi percaya diri. Anak yang belum mampu untuk bersikap mandiri menjadi lebih mandiri. Menurut ibu Retno anaknya sangat senang melakukan pekerjaan sendiri, misalnya mandi inginnya mandi sendiri tanpa bantuan dari siapapun. Masih menurut beliau, dari menitipkan anaka di TPA Ibunda beliau mendapat dua keuntungan; yang pertama, beliau merasa tenang dan aman jika anak dititipkan di TPA Ibunda; kedua, banyak memberikan perubahan positif yang terjadi kepada anaknya.

Selain dari hasil wawancara dengan orang tua dari anak asuh di Taman Pentipan Ibunda, kami juga mendapatkan data dokumentasi tentang mendidik kemandirian anak. Seperti yang ada di foto dibawah ini, menunjukkan bahwasannya anak-anak yang ada di TPA Ibunda diajarkan untuk kemandirian seperti melalakukan makan dengan cara makan sendiri dengan tertib tanpa mengganggu temannya yang lain. 


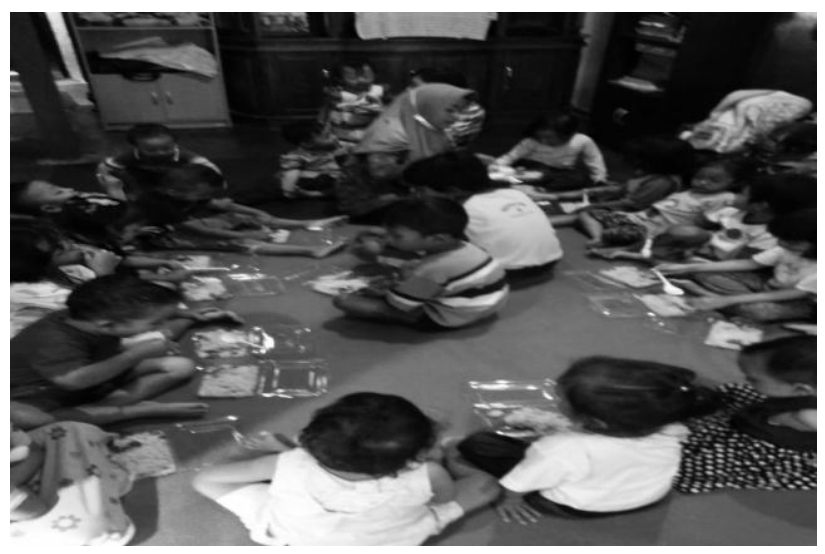

Gambar 1. Makan secara mandiri.

Di Tempat Penitipan Anak Ibunda, selain melakukan kegiatan rutin yang sudah terjadwal di TPA, juga dilakukan kegiatan-kegiatan yang menunjang pertumbuhan dan perkembangan anak khususnya pada perkembangan sosial emosional anak usia dini. Yaitu seperti, mengadakan lomba-lomba memperingati hari kemerdekaan, mengikuti kegiatan-kegiatan yang diadakan oleh HIMPAUDI Ponorogo, dll. Seperti dokumentasi yang diperoleh peneliti, yaitu

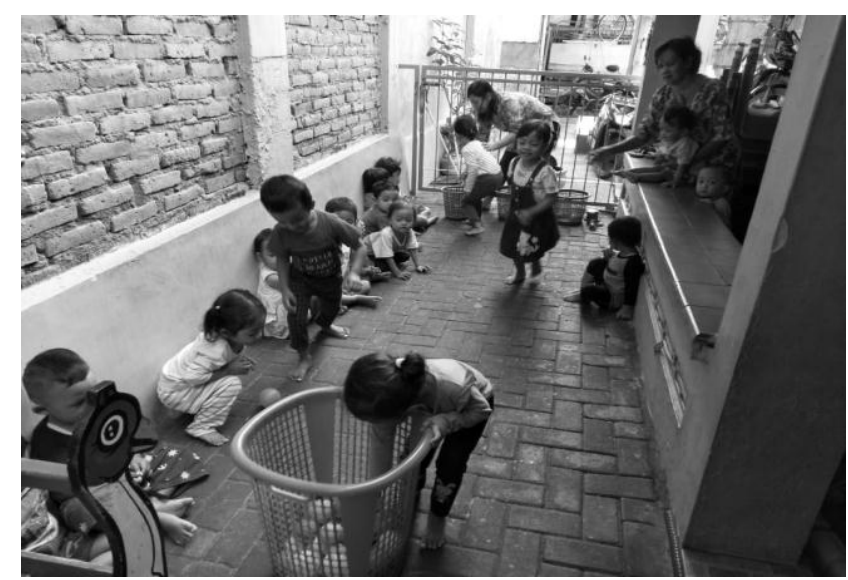

Gambar 2. Kegiatan penunjang di TPA Ibunda

Kegiatan diatas menunjukkan kegiatan penunjang yaitu lomba memasukkan bola ke dalam keranjang. Kegiatan tersebut melatih anak bersikap kerjasama, terampil dan control diri.

Dari beberapa pernyataan diatas, dapat diambil kesimpulan bahwa, pembelajaran atau pola pengasuhan yang dilakukan oleh team pengasuh Tempat Penitipan Anak Ibunda memberikan efek positif yang signifikan. Anak-anak yang dititipkan di TPA tersebut, menjadi lebih percaya diri, mandiri, dan bisa bersikap lebih bersahabat serta control diri yang baik. 
Seperti yang sudah dipaparkan pada kajian teori bahwasannya, seiring berkembangnya sosial dan emosi pada anak dengan baik maka akan membentuk sikap mental dan karakter, yaitu sifat tanggung jawab, bisa beradaptasi dengan lingkungan sosial, bisa menerima aturan, terampil dalam komunikasi, bisa menyelesaikan masalah dan lain sebagainya.

\section{Catatan Akhir}

Strategi pengasuhan yang dilakukan di Tempat Penitipan Anak "Ibunda" menggunakan pola asuh demokratis dengan mengedepankan sosial emosional anak yang berlandaskan pada antusiasme anak, rasa senang dan gembira serta tidak memberikan aturan yang mengekang ekspresi anak. Aturan-aturan yang dibuat di TPA adalah untuk mengontrol sikap dan sifat demi terarahnya kepada pembentukan karakter yang lebih baik.

Implikasi pola pengasuhan demokratis di Tempat Penitipan Anak Ibunda memberikan efek positif yang signifikan. Anak-anak yang dititipkan di TPA tersebut, menjadi lebih percaya diri, mandiri, dan bisa bersikap lebih bersahabat serta control diri yang baik.

\section{Daftar Rujukan}

Nugraha, Ali (2012) Metode Pengembangan Sosial Emosional. Tangerang: Universitas Terbuka.

Aisyah, Siti, dkk (2015) Perkembangan dan Konsep Dasar Pengembangan Anak Usia Dini. Tangerang Selatan: Universitas Terbuka.

Direktorat Pembinaan Pendidikan Anak Usia Dini Direktorat Jenderal Pendidikan Anak Usia Dini Dan Pendidikan Masyarakat Kementerian Pendidikan Dan Kebudayaan. 2015. Petunjuk Teknis Penyelenggaraan Taman Penitipan Anak. TT: TP

Sujiono, Yuliani Nurani (2011) Konsep Dasar Pendidikan Anak Usia Dini. Jakarta: Indeks.

Suyadi (2015) Teori Pembelajaran Anak Usia Dinidalam Kajian Neurosains, Bandung: Remaja Rosdakarya.

Ayuda Jati Putri \& Hermien Laksmiwati (2013). Perkembangan Sosial Anak Usia Dini Di Taman Penitipan Anak (TPA) Melati School Ketintang Tengah - Surabaya. Jurnal: Character, Volume 02 Nomor 02, 5.

Wiyani, Novan Ardi (2014) Mengelola dan Mengembangkan Kecerdasan Sosial dan Emosi Anak Usia Dini. Yogyakarta: Ar-Ruz Media.

Mansur (2005) Pendidikan Anak Usia Dini Dalam Islam. Yogyakarta: Pustaka Pelajar.

Tridhonanto, Al (2014) Mengembangkan Pola Asuh Demokratis Jakarta: PT Alex Media Komputindo.

Sugiyono (2015) Memahami Penelitian Kualitatif. Bandung: Alfabeta.

Sugiyono (2018) Metode Penelitian Kuantitatif, Kualitatif, dan R\&D. Bandung: Alfabeta

Sukmadinata, Nana Syaodih (2005) Metode Penelitian Pendidikan. Bandung: Remaja Rosdakarya.

Suyadi dan Maulidya Ulfa (2015) Konsep Dasar Paud. Bandung: Remaja Rosdakarya. 
Suyadi (2015) Teori Pembelajaran Anak Usia Dinidalam Kajian Neurosains. Bandung: Remaja Rosdakarya.

W.Creswell, John (1998) Qualitative Inquiry and Research Design: Choosing Among Five Tradition. London: SAGE Publications.

Wiyani, Novan Ardi (2014) Mengelola dan Mengembangkan Kecerdasan Sosial dan Emosi Anak Usia Dini. Yogyakarta: Ar-Ruz Media. 